\title{
How globalization became a thing that goes bump in the night
}

\author{
Stephen J. Kobrin \\ William Wurster Professor Emeritus of \\ Multinational Management, The Wharton School, \\ University of Pennsylvania, Philadelphia, \\ PA 19104, USA \\ Correspondence: \\ S) Kobrin, William Wurster Professor \\ Emeritus of Multinational Management, The \\ Wharton School, University of Pennsylvania, \\ Philadelphia, PA 19104, USA \\ e-mail: kobrins@wharton.upenn.edu
}

\begin{abstract}
For almost 200 years, globalization has been seen as a positive development, albeit with costs and benefits, and as progress and modernization, a broadening of humanity's scope from the local and parochial to the cosmopolitan and international. That changed dramatically with the Great Recession, the waves of migration of the last decade, and the global Coronavirus (COVID-19) pandemic of 2020. For many, globalization now connotes economic dislocation, increasing inequality, unwanted immigration, and a vehicle for the transmission of disease. The pandemic reminds us that most economic activity takes place within national borders. It has emphasized the dangers rather than the benefits of efficient linkages between markets, laying bare the dangers of complex global supply chains where any node can become a "choke point", and the risks of overspecialization or the concentration of technological knowledge and/or production capacity in a single country or region. A more positive view of globalization will require restoring the balance between independence and integration, mitigation of its costs within and between countries, and dealing with redundancy and supply risk.

Journal of International Business Policy (2020) 3, 280-286. https://doi.org/10.1057/s422 I4-020-00060-y
\end{abstract}

Keywords: globalization; COVID-19; anti-globalization; supply chains; international economic integration

Everything is designed to become interconnected. Tourists and terrorists, arms and drugs...algorithms, messages, diseases...travel across borders, make, enjoy, or suffer history in the Global Age

(Schafer, 2003: 84).

\section{INTRODUCTION}

For almost 200 years, globalization has been seen as a positive development - albeit with costs and benefits - if not an imperative, and as progress and modernization, a broadening of humanity's scope from the local and parochial to the cosmopolitan and international. While that sentiment was certainly not universal, for much of this period it was dominant.

That changed dramatically with the Great Recession of 2008, the waves of migration characteristic of the last decade, and, finally, the global Coronavirus (COVID-19) pandemic of 2020. For many, globalization now connotes economic dislocation and increasing 
inequality, unwanted immigration, and, most recently, a vehicle for the transmission of disease.

While Marx and Engels (1998 (1848): 39) bemoaned the destruction of "old-established national industries", they went on to say that, "to the great chagrin of reactionists," bourgeois exploitation of the world market has given "a cosmopolitan character to production and consumption in every country." Trotsky (1928) argued that the most advanced productive forces, the application of electricity and chemistry to the processes of production, were incompatible with national boundaries.

At the other end of the political spectrum, the Geneva School of Neoliberals believed that commitments to national sovereignty and autonomy were dangerous; that the "cardinal sin of the twentieth century was the belief in unfettered national independence."; and that "nations must remain embedded in an international institutional order that safeguarded capital and its right to move throughout the world" (Slobodian, 2018: 9).

Keynes waxed eloquently about the global age that came to an end in 1914. "An inhabitant of London [of a certain class] could order by telephone, sipping his morning tea in bed, the various products of the whole earth...and reasonably expect their early delivery upon his doorstep...He could secure...cheap and comfortable means of transit to any country or climate without passport or other formality" (1920: 11).

There was a sense of inevitability associated with globalization, a sense of progress, and of a broadening of narrow, parochial, and local interests; a sense of inevitability driven by developments in transport and communication that linked markets and individuals and dramatically increased the ease and efficiency of international trade and investment. In a famous article at the turn of the twentieth century, Mackinder (1904) argued that, with the end of the Columbian epoch of exploration and thanks to improvements in transport, there now was a single, closed political system, worldwide in scope. A century later, with the digital revolution, container shipping, and jet aircraft, a great many citizens of the advanced countries were able to "order the various products of the whole earth" and expect 2-day delivery to their doorstep.

The late nineteenth century global economy lost much of its steam with the outbreak of World War I, and ended precipitously with the depression following the American stock market crash in 1929.
In 1930, the U.S. Congress passed the SmootHawley tariff which imposed levies on over 20,000 goods and was met by almost immediate retaliation by the other major trading nations.

What is important here is that Smoot-Hawley was seen by most observers as a mistake. The tariff was opposed by over 1000 economists and was remedied after the election of Roosevelt with the passage of the Reciprocal Tariff Act of 1934. When Churchill and Roosevelt issued the Atlantic Charter in 1941, summarizing post-War aims, one of the eight points called for the lowering of trade barriers.

In 1945, immediately after the second World War, negotiations began for an International Trade Organization. While an agreement proved problematic, the GATT (General Agreement on Tariffs and Trade) was established in 1947 and it provided a framework for trade negotiations until the World Trade Organization (WTO) was established in 1995.

Although there has been substantial opposition to both globalization in general and its institutions, in particular, the International Monetary Fund and the WTO, that opposition tended to focus on welfare effects (the distribution of the gains from trade), sectoral impacts, or effects on developing countries. Although it may be an over-generalization, it is fair to say that, until the very late twentieth century, globalization was seen as a net positive, that international trade, investment, and economic integration (e.g., the European Union) allowed both the more efficient use of the world's resources and the development of large-scale technology. Economic nationalism was seen as problematic, as a barrier to further international economic integration: as Habermas (2001) argued, there was a need for politics to catch up with economics.

Late twentieth century globalization became synonymous with the idea of a hyper-efficient networked world economy. The combination of the digital revolution and dramatic improvements in transport allowed the value chain to be broken into small units or tasks with every task located wherever in the world it could be performed most efficiently. Geography was seen as ambiguous in a "post-modern" economy (Kobrin, 1997). Network theory emphasized the direct connections between nodes, as opposed to a hierarchical organization of local to national to global scales: plants or financial institutions interacted directly with multiple sites in other countries without the need to go through the organizational structure of the multinational 
corporation. The emphasis was on the linkages rather than the nodes, an assumption that the nodes or sites where specific tasks are performed were dependent for their value on the network as a whole.

\section{THE RISKS OF GLOBALIZATION BECOME OBVIOUS}

The combination of the rise of populist nationalism with the Great Recession and the COVID-19 pandemic has stood these arguments on their head, and emphasized the dangers rather than the benefits of the efficient linkages between markets (Rodrik, 2018a). Most obviously, the extensive and rapid international travel associated with globalization served as an ideal medium for the very rapid spread of the Coronavirus: it became global in just a few months after first being isolated in China.

The global pandemic reminds us that, at the end of the day, most economic activity does take place within national borders. It has again focused attention on the nodes, laying bare the dangers of complex global supply chains where any node can become a "choke point" that threatens to close down the entire network. It has also revealed the very real risks of letting efficiency drive the concentration of supply of critical goods and materials into a single market; the "destruction of oldestablished national industries" is no longer taken as an indicator of progress.

My objective in this essay is to focus on the impacts of the Coronavirus pandemic on how globalization is perceived. That said, it is clear that the Great Recession of 2008 was a turning point and that the economic dislocation and inequalities that it revealed, combined with the reaction against large-scale migration into the developed countries, resulted in a populist reaction against international integration - social and political as well as economic. That was exploited by economic nationalists such as Donald Trump in the U.S. and Viktor Orban in Hungary and the "leavers" in Britain who promoted Brexit.

While it has always been acknowledged that globalization entails both benefits and costs, it was generally assumed that the former far outweighed the latter, and that the welfare or distributional effects could be dealt with nationally. However, by the late twentieth century, the consensus that trade has only modest effects on income distribution became increasingly dated (Autor, Dorn, \& Hanson,
2003; Krugman, 2008). In what seemed at the time as a rapid reversal of opinion, globalization became a negative rather than a positive, a threat to social, cultural, and political as well as economic wellbeing (see Kobrin, 2017, for a more complete discussion of this point.)

This was clear in a recent New York Times article describing globalization (of recent decades) as "an underregulated, complacent form of interconnection that has left communities vulnerable to a potent array of threats" (Goodman, 2020: B4). COVID-19 dramatically exposed one of the most potent threats: the rapid transmission of the infection globally through the complex web of international air travel (and cruises). The World Health Organization (WHO) first announced the new virus in China on January 11, 2020, by early February it had spread to seven Asian countries, five in Europe, and to the U.S. and Canada. The WHO declared it a pandemic on March 10, and by May 7 there were 3.8 million cases worldwide and 260,000 deaths (World Health Organization, 2020).

The response was almost as immediate and very physical: one nation after another closed their borders and banned non-essential travel - the very antitheses of globalization. As of April 15, at least 93 percent of the global population lived in countries with coronavirus-related travel restrictions, and about 3 billion people were living in countries enforcing complete border closures to foreigners (Salcedo \& Cherelus, 2020). The U.S. State Department has issued a level 4 "do not travel" advisory and the U.S.-Canadian and U.S.-Mexican borders were closed. On April 11, President Macron of France announced that the Schengen member countries were considering extending the closing of their borders until September.

For much of the twentieth century and the first decade of the twenty-first, globalization was an abstraction to much of the world's population. Especially when economies were strong, economic dislocations attributable to globalization - while very real to those suffering the consequences - were limited in scope. That changed dramatically during the last decade. With the Great Recession, the negative economic impacts of globalization became much more widespread, directly affecting the middle classes of many industrial countries.

That said, it took large-scale migration and the COVID pandemic to firmly establish globalization as a widely seen threat. The waves of migrants fleeing conflict zones such as Syria, and abject poverty and violence in Africa and Latin America, 
were very visible and immediate and leveraged by xenophobic groups to turn significant numbers of citizens of many countries against both immigrants specifically and globalization more generally. Globalization was no longer abstract: it was waves of immigrants washing up on beaches in Greece or President Trump warning of "armies of migrants" marching to invade America's southern border.

The COVID pandemic was the next nail in the coffin. Globalization and international travel became associated with an immediate and very visible threat - serious illness and death. Globalization is no longer an abstraction to most of the world's population. It carries negative connotations as a vehicle for the transmission of a serious and potentially fatal disease, and the economic chaos associated with it, in virtually every country.

\section{OVERSPECIALIZATION AND CONCENTRATION OF PRODUCTION}

Digital communications provide for simultaneity in time without regard for space, and facilitate the creation of relational networks of flows for the coordination of complex processes without regard for place or geographic distance (Amin, 2002). That, in turn, has allowed for the extension of specialization - in every phase of the production process - with scant regard for national borders. This drive for efficiency combined with technological path dependence has resulted in the concentration of knowledge - in both research and development and production processes - in specific and often limited geographic areas.

Benefits of the application of the digital revolution to research and production include a dramatic increase in the rate of innovation and the flow of a very wide range of affordable products to consumers worldwide. A broad spectrum of inhabitants of most of the countries of the developed world had access to "the various products of the whole earth" in remarkably short order and at an affordable cost.

That came with a price in terms of the loss of jobs, especially in developed countries' manufacturing sector, a price which became very obvious with the Great Recession and certainly played a role in the surge of populist nationalism in many countries. (Advances in manufacturing technology are also relevant.) The COVID-19 pandemic, however, revealed that, regardless of the simultaneity of time, the disregard of space - of geography entailed very significant risks. Both overspecialization or the concentration of technological knowledge and/or production capacity in a single country or region and the reliance on complex global supply chains proved problematic.

Ironically, some of the earliest indications of the dangers of overspecialization came from shortages of materials and drugs needed to treat the virus itself. Chinese manufacturers produced half of the world's medical masks, and the production of reagents, a component of test kits, is dominated by just two companies (Farrell \& Newman, 2020). As plants were shut down in China and other countries, the flow of these very necessary supplies was significantly restricted and the ability to shift the location of production was limited.

Similarly, India has become the world's main supplier of generic drugs, and they, in turn, rely on China for 70 percent of the active pharmaceutical ingredients (APIs) for their medicines. In March 2020, India restricted export of 26 of these APIs and the medicines made from them in order to insure an adequate supply for the domestic market in the face of the COVID pandemic. Europe was described in the press as "panicking" over the possible impacts on supplies of necessary medications, and the U.S. Food and Drug Administration noted that Indian imports accounted for almost a quarter of medicines in 2018 (Dasgupta \& Burger, 2020).

In another of the COVID ironies, at a time when a good portion of humanity is confined to their home, the lockdown in Malaysia has resulted in concern about a "devastating condom shortage", as a single plant in that country produces 20 percent of the world's condoms (France 24, 2020).

As the pandemic spread, countries went into "lockdown" mode, production was disrupted, the trade-off between efficiency (lower prices and technological specialization) and security of supply became obvious as shortages, or threats of shortages, became evident. As with many issues related to international trade, the benefits in terms of a lower cost of goods, while widespread, are not always obvious while the costs - job losses or in this case, shortages of critical goods - bear more directly on specific industries and consumers.

\section{RISKS OF COMPLEX GLOBAL SUPPLY CHAINS}

Both the rise of economic nationalism (e.g., America First) and the COVID pandemic revealed the serious risks of reliance on very complex networks of global supply chains in many industries. Both have reemphasized the importance of places as opposed to flows, of the possibility that any given 
node in the network could serve as a "choke point," disrupting or shutting down the entire supply chain (Farrell \& Newman, 2020). The U.S. auto industry, for example, relies heavily on parts sourced from China and their suppliers rely on Chinese tool and die makers.

For example, there is concern that the COVID pandemic could result in a global food crisis in no small part due to supply chain disruption. As a recent Atlantic Council report (Terp \& Jahn, 2020) noted, "(L)arge amounts of seeds, fertilizer, and agro-chemicals are shipped between ports. As a result, ports can form a single point of failure in a complicated system, particularly where a country or region is heavily reliant on freight through a specific port." Needless to say, any disruption of the food supply, in advanced or developing countries, will affect a broad swath of the population and certainly be seen as a risk of globalization.

Consumer electronics have complex supply chains that could certainly be affected by the virus. For example, virtually all of Apple's iPhones are assembled in China. The lockdown in Malaysia impacted chip and circuit board suppliers, while the engineers who work on cellular modems are in Germany and the plants that produce power management chips are located in Italy, Germany, and the UK, all suffering shut downs due to COVID-19 (Eadicicco, 2020).

A consumer who may use an iPhone daily without thinking about the marvels of the complex global supply chain that brought it to them, will certainly become aware of the risks of globalization when a part needed for a repair or even a replacement phone is not available. As noted above, unlike Lord Keynes, the majority of the population most likely does not spend time marveling at the fact that global economic integration provides a vast cornucopia of goods at an affordable price. It is taken as the norm. However, the disruption of that flow of goods is inherently obvious to most observers and is certainly not taken as a normal state of affairs.

\section{A LACK OF LEADERSHIP}

While America's leadership of the global economy since 1945 has been viewed ambivalently, it has also been seen by many as necessary. A stable, open international economy requires a hegemon, a dominant power who can provide some of the necessary public goods, absorb costs, and order the system. As Kindleberger (1986) observed, the inability of U.K. and the unwillingness of the United States to continue or assume that leadership role was one of the primary causes of the collapse of the first global economy and the Great Depression.

It is reasonable to argue that the U.S. is now neither willing nor able to assume leadership of the global economy, and that it will be difficult for either China or Europe to take its place in the near future, resulting in what Bremmer (2011) has called a "G-0 World." The instability that is likely to result will certainly add to the negative views of globalization held by many.

More generally, the repudiation of international economic integration and of the international system established after WWII to facilitate flows of trade and investment by the two countries most responsible for its birth - "America First" and Brexit - has unquestionably contributed to a more negative view of globalization. The leaders of both countries have demonized internationalism in general and opposed international economic, cultural, and social exchanges more specifically.

\section{THE FUTURE}

While my purpose here is analysis rather than forecasting, it is reasonable to ask whether globalization will continue to be seen as "the thing that goes bump in the night." Over the last century and a half, globalization has been a cyclical phenomenon, and there is reason to believe that we have reached a plateau if not the peak of the second, late twentieth century wave. At the same time, we face an increasing flow of anti-globalization rhetoric and perceptions, fanned by populists taking full advantage of the COVID-19 pandemic.

The emergence of a more positive view of globalization will require at least three major interrelated changes to minimize its costs while still taking advantage of its benefits: first, restoring the balance between economic independence and integration; second, mitigation of the costs of globalization both within and between countries; and last, insuring some degree of redundancy and supply risk mitigation.

Ever since Adam Smith's argument for specialization in the manufacture of pins, the quest for economic efficiency has driven larger and largerscale integration of production, both in terms of 
plant size and geographic scope. By the late twentieth century, specialization - of both production and technology - was truly global in scope, and borders were no longer significant barriers to the flow of goods and ideas.

Hyper-globalization (Rodrik, 2018b) entailed both great benefits and great risks. The unprecedented access to a wide range of more affordable goods and rapid technological development came with an unprecedented degree of economic (and political) interdependence and economic dislocation in advanced countries.

It is reasonable to argue that what the U.S. Trade Representative has called a "lemming-like desire for efficiency" (Lighthizer, 2020) and lower costs may have gone too far and that some balance between integration and national independence needs to be restored. Restoring that balance, however, is a politically fraught, and an overreaction is likely. That overreaction will be compounded by populist demagogues exploiting the fear of the "other" who exacerbate concerns about socio-cultural integration.

Second, the costs in terms of dislocation and inequality will have to be dealt by each country on its own terms. Within countries, more efforts will have to be made to offset the costs of globalization through retraining and social welfare programs, and to more fairly distribute the benefits. That will certainly require income transfers to both support welfare efforts and effect redistribution. To say that is politically fraught, given ideological differences among countries and the political influence of wealth in many, is an understatement.

Restoration of a positive attitude towards globalization will also require transfers between countries. The very negative reaction to the wave of migrants reaching Europe is certainly a significant factor in the rise of anti-globalization sentiment. National and multi-national efforts to stem the flow through interdiction have very obvious limits. In the long run, the only solution, in both Europe and the U.S., is to try to remedy the problem at its source: to increase standards of living in the countries that are the sources of migrants. That will also require income and wealth transfers of various forms from wealthy to poor countries. Again, to say that an effort of that sort would be unpopular given current conditions is an understatement.

Last, some degree of redundancy and supply risk mitigation will have to be built into the system. Regardless of efficiencies, the pandemic has shown that severe problems can result from depending on single sources of supply for critical products or technologies. Similarly, complex global supply chains have proven vulnerable to problems at "choke points" that can bring the entire production process to a halt.

Resolving problems resulting from single-sourced products or technologies and complex supply chains will involve a large number of private firms, both global and national. Coordination problems both within and across countries will be immense and conflicts between a firm's objectives and national interest will prove difficult to resolve.

None of this bodes well for a dramatic change in attitudes about globalization in the short run. The COVID-19 pandemic has raised some very real problems arising from global integration - social and political as well as economic - and reinforced national feeling and fears of "the other" that are all too easy to exploit.

That said, the pandemic itself demonstrates that disintegration or de-globalization has its limits; it is one of a number of critical problems of a scale that require international cooperation. A successful search for a vaccine will require a global effort. While political borders may be closed, scientists have been "creating a global collaboration unlike any in history. Never before, researchers say, have so many experts in so many countries focused simultaneously on a single topic [development of a vaccine] and with such urgency" (Apuzzo \& Kirkpatrick, 2020).

Climate change is another existential problem that cannot be dealt with on a country by country basis. No single country can prevent rising sea levels from "invading" its territory and mitigation demands global cooperation. Unfortunately, that conclusion is not yet shared by all.

It will be difficult to achieve that cooperation in the face of the economic nationalism characteristic of the world at this point. In particular, the "mutual vilification" between the United States and China, the two major powers, is limiting cooperation between them, and the current geopolitical 
environment creates a climate more conducive to national competition than international cooperation (Sanger, Kirkpatrick, Zimmer, Thomas, \& Wee,
2020). We are in great danger of throwing the baby out with the bathwater.

\section{REFERENCES}

Autor, D., Dorn, D., \& Hanson, G. H. 2003. The China syndrome: Local and labor market effects of income competition in the United States. American Economic Review, 103(6): 2121-2168.

Amin, A. 2002. Spatialities of globalization. Environment and Planning A, 34: 385-399.

Apuzzo, M. \& Kirkpatrick, D. D. 2020. COVID-19 changed how the world does science, together. New York Times. New York.

Bremmer, I. \& Roubini, N. 2011. A G-0 world: The new economic club will produce conflict not cooperation. Foreign Affairs 90(2):2-7.

Dasgupta, N. \& Burger, L. 2020. Euprope panicking over India's pharmaceutical export curbs. Business News. Retrieved April 28, 2020, from https://www.reuters.com/article/us-healthcoronavirus-india-drugs/europe-panicking-over-indiaspharmaceutical-export-curbs-industry-groupidUSKBN20R1MD.

Eadicicco, L. 2020. Apple's supply chain still strugeling to retrun to normal even a China recovers from the pandemic. Retrieved April 28, 2020, from https://www.businessinsider.com/ coronavirus-apple-supply-chain-iphone-12-production-20203.

Farrell, H. \& Newman, A. I. 2020. WIII the corona virus end globalization as we know it. Foreign Affairs: This Week. Retrieved March 23, 2020, from https://link.foreignaffairs. com/view/5d882464954fcf68254f40f9brsrn.55vw/ Oaabd915.

France 24. 2020. Virus may spark devastating global condom shortage. Retrieved April 28, 2020, from https://www. france24.com/en/20200408-virus-may-spark-devastatingglobal-condom-shortage.

Goodman, P. S. 2020. Virus adds to backlash in a world intertwined. New York Times. New York, B1, B4.

Habermas, J. 2001. The postnational coalition: Political essays. Cambridge: MIT Press.

Keynes, J. M. 1920. The economic consequences of the peace. New York: Harcourt, Brace, and Howe.

Kindleberger, C. P. 1986. The world in depression, 1929-39. Berkeley: The University of California Press.

Kobrin, S. J. 1997. The architecture of globalization: State Sovereignty in a networked global economy. In J. H. Dunning (Ed.), Governments, globalization and international business: 146-172. Oxford University Press: Oxford.

Kobrin, S. J. 2017. Bricks and Mortar in a borderless world: Globalization, the backlash and multinational enterprise. Global Strategy Journal, 7(2): 159-171.
Krugman, P. R. 2008. Trade and wages, reconsidered. Brookings Papers on Economic Activity, 2008: 103-137.

Lighthizer, R. E. 2020. The era of offshoring of U.S. jobs is over. New York Times, May 12, A27.

Mackinder, H. J. 1904. The geographical pivot of history. The Geographical Journal, XXIII: 421-445.

Marx, K. \& Engels, F. 1998 (1848). The communist manifesto. London, Verso.

Rodrik, D. 2018a. Populism and the econommics of globalization. Journal of International Business Plolicy, 1(1-2): 12-33.

Rodrik, D. 2018b. Straight talk on trade: Ideas for a sane world economy. Princeton: Princeton University Press.

Salcedo, A. \& Cherelus, G. 2020. Coronavirus travel restrictions, across the globe. New York Times. New York.

Sanger, D., Kirkpatrick, D. D., Zimmer, C., Thomas, K., \& Wee, S.-L. 2020. Profits and pride at stake, the race for a vaccine intensifies. New York Times. New York.

Schafer, W. 2003. The new global history: Toward a narrative for pagaea two. Erwagen Wissen Ethik, 14(1): 75-88.

Slobodian, Q. 2018. Globalists: The end of empire and the birth of neoliberalism. Cambridge: Harvard University Press.

Terp, S.-J. \& Jahn, M. 2020. Earth Day 2020 call for action: Mitigating the global food crisis associated with COVID-19. Retrieved April 28, 2020, from https://www.atlanticcouncil. org/blogs/geotech-cues/mitigating-the-impacts-of-globalfood-crises-associated-with-covid-19.

Trotsky, L. 1928. The third international after lenin. Retrieved March 16, 2020, from https://www.marxists.org/archive/ trotsky/1928/3rd/ti03.htm.

World Health Organizaton. 2020. Situation reports. Retrieved May 8, from https://www.who.int/emergencies/diseases/ novel-coronavirus-2019/situation-reports.

\section{ABOUT THE AUTHOR}

Stephen J. Kobrin is William Wurster Professor Emeritus of international Management at the Wharton School of the University of Pennsylvania. His research focuses on the interrelationships between international business and international politics.

Accepted by Sarianna Lundan, Editor-in-Chief, 26 May 2020. This paper is part of a series of contributions dealing with the implications of the Covid-19 pandemic on international business policy, and it was single-blind reviewed.

Publisher's Note Springer Nature remains neutral with regard to jurisdictional claims in published maps and institutional affiliations. 